\title{
Integrative review of literature: nursing care to aged people with HIV
}

\author{
Revisão integrativa da literatura: assistência de enfermagem a pessoa idosa com HIV \\ Revisión integrativa de la literatura: asistencia de enfermería a la persona anciana con VIH
}

\section{Arayana Gomes da Silva', Viviane Siqueira Cavalcanti', Tâmyssa Simões dos Santos', Gabriela Rodrigues Bragagnollo'"I , Karen da Silva Santos'"' , Ivanilde Miciele da Silva Santos' , Kristiana Cerqueira Mousinho" , Cinira Magali Fortuna"'I}

' Centro Universitário Mauricio de Nassau. Maceió, Alagoas, Brazil.

"Centro Universitário Cesmac. Maceió, Alagoas, Brazil.

"' Universidade de São Paulo. Ribeirão Preto, São Paulo, Brazil.

\begin{abstract}
How to cite this article:
Silva AG, Cavalcanti VS, Santos TS, Bragagnollo GR, Santos KS Santos IMS, et al. Integrative review of literature: nursing care to aged people with HIV. Rev Bras Enferm [Internet]. 2018;71(suppl 2):884-92.

[Thematic Issue: Health of the Elderly] DOI: http://dx.doi.org/10.1590/0034-7167-2017-0264
\end{abstract}

Submission: 04-25-2017 Approval: 07-16-2017

\begin{abstract}
Objective: To identify evidences in scientific Brazilian literature on nursing care to aged people with HIV. Method: Integrative review of literature from databases: Latin American and Caribbean Literature on Health Sciences (LILACS), Scientific Eletronic Library Online (SciELO), Cochrane and the Nursing Database (BDENF). The applied inclusion criteria were publications that were fully available from 2001 to 2015 and answered to the guiding question of this study. Results: We included 13 studies; and the categories that allowed a better presentation of the scientific evidence on nursing care to aged people with HIV carrier were: Epidemiological profile, perceptions and experiences of aged people with HIV and nursing care to aged people with HIV. Conclusion: The studies address nursing care from a clinic that follows NANDA diagnoses of strong individualizing approach and low consideration of social aspects.
\end{abstract}

Descriptors: Nursing Assessment; Sexuality; Aging; AIDS Serodiagnosis; Nursing Care.

\section{RESUMO}

Objetivo: Identificar na literatura brasileira as evidências científicas sobre a assistência de enfermagem ao idoso portador do HIV. Método: Revisão integrativa da literatura, realizada nas bases de dados: Literatura Latino-Americana e do Caribe em Ciências da Saúde (LILACS), Scientific Eletronic Library Online (SciELO), Cochrane e a Base de Dados em Enfermagem (BDENF). Os critérios de inclusão aplicados foram publicações que estivessem disponíveis na íntegra, no período de 2001 a 2015, e que respondesse a questão norteadora do estudo. Resultados: Foram incluídos 13 estudos; e as categorias que permitiram uma melhor apresentação das evidências científicas sobre a assistência de enfermagem ao idoso portador do HIV, foram: Perfil epidemiológico, percepções e vivências dos idosos portadores de HIV e Assistência de enfermagem frente ao idoso soropositivo. Conclusão: Os estudos abordam a assistência de enfermagem ainda através de uma clínica baseada nos diagnósticos da NANDA com forte abordagem individualizante e baixa consideração dos aspectos sociais.

Descritores: Avaliação em Enfermagem; Sexualidade; Envelhecimento; Sorodiagnóstico da Aids; Cuidados de Enfermagem.

\section{RESUMEN}

Objetivo: Identificar en la literatura brasileña las evidencias científicas sobre la asistencia de enfermería al anciano portador del VIH. Método: Revisión integrativa de la literatura, realizada en las bases de datos: Literatura Latinoamericana y del Caribe en Ciencias de la Salud (LILACS), Scientific Eletronic Library Online (SciELO), Cochrane y la Base de Datos en enfermería (BDENF). Los criterios de inclusión aplicados fueron las publicaciones que estuvieron disponibles en la versión completa, en el período de 2001 a 2015, y que respondiera la cuestión orientadora del estudio. Resultados: Fueron incluidos 13 estudios; y las categorías que permitieron una mejor presentación de las evidencias científicas sobre la asistencia de enfermería al 
anciano portador del VIH, fueron: El Perfil epidemiológico, las percepciones y las vivencias de los ancianos portadores de VIH y la Asistencia de enfermería delante el anciano seropositivo. Conclusión: Los estudios abordan la asistencia de enfermería todavía a través de una clínica basada en los diagnósticos de NANDA con fuerte abordaje individualizante y baja consideración de los aspectos sociales.

Descriptores: Evaluación en Enfermería; Sexualidad; Envejecimiento; Serodiagnóstico del Sida; Cuidados de Enfermería.

\section{INTRODUCTION}

The aging process has been more and more common proportionally to economic development. At each year, it is possible to observe the need to provide more accurate health services to aged people ${ }^{(1)}$.

Despite the favorable conception on the aging process, the increase in life expectancy in Brazil has been referred as negative regarding the epidemiological framework of sexually transmitted diseases, becoming more common among the aged ${ }^{(2)}$.

Among venereal diseases, authors ${ }^{(3)}$ state that HIV (Human Immunodeficiency Virus) and the consequent increase in the number of cases of Aids (Acquired Immunodeficiency Syndrome) are more common in this population.

A study from Chile, where the conduction of data collection was through information on people with HIV/Aids given by the Spanish National Center of Epidemiology, showed that both Caribbean and Latin America have higher prevalence rates of HIV/Aids in adults, mainly because of the religious, cultural, economic and political factors that influence the population's sex behaviors ${ }^{(4)}$.

This pathology also represents a Brazilian significant public health problem not only because of its debilitating elements of physiological character, but also of its psychic and social issues associated with the stigma around the disease ${ }^{(3)}$.

Regarding HIV epidemiology in Brazil, there were 39.185 cases of Aids in Brazil by 2012 with a detection rate of 20.2 to 100.000 inhabitants. The Northeast region achieved the level of 14.8 cases/100.000 inhabitants. There was a total of 1.250 cases in the state of Alagoas mainly featured in Maceió, Arapiraca, União dos Palmares, Rio Largo e São Miguel dos Campos ${ }^{(5)}$.

According to the National Program of DST/Aids of the Brazilian Ministry of Health, in the last three decades, there were 13,665 cases of people aged 60 years or more, $34.36 \%$ of them affecting females ${ }^{(6)}$. Such epidemiological design shows the need to change the idea that aged people are sexually inactive, only considering the young population as part of the risk group of sexually transmitted infections (STIs). By not comprising aged people in HIV risk group, this conception expressively contributes to increases in the number of cases and the lack of strategies that might favor a change of paradigm ${ }^{(1)}$.

The possibility of HIV infection in the aged population is an aspect ignored in the development of more effective public policies, generally limited to young people, which is associated with the fact that aged people not using condoms, especially among climacteric and hysterectomized women, or who cannot get pregnant for any reason, thus seeing no point for using condoms ${ }^{(7)}$.

However, the lack of concern on the sexuality of the aged is not only seen in the public policy and assistance actions field, but also on the scientific one, considering the literature usually addresses sexuality from the adolescent's perspective, not producing enough publications on aged people with HIV, especially regarding the contributions of nursing care to patients with this disease ${ }^{(7)}$.

\section{OBJECTIVE}

To identify evidences in the scientific Brazilian literature on nursing care to aged people with HIV.

\section{METHOD}

This is an integrative literature review that allows the inference of questions on the nursing care of aged people with HIV. The integrative review of literature aims at offering research results based on a guiding question using a systematic planning that can contribute to the understanding how literature has been referring to nursing care to aged people with HIV in a more accurate way ${ }^{(8)}$. The theme of this production was based on the following guiding question: How nursing care to aged people with HIV is addressed by Brazilian literature?

We did a research on a scientific database from January 2015 to October 2015 using the advanced search form in the following databases: Latin American and Caribbean Literature in Health Sciences (LILACS), Scientific Eletronic Library Online (SciELO), Cochrane and Nursing Database (BDENF), by using Health Sciences Descriptors (DECS): "HIV", "idoso" [aged people], "enfermagem" [nursing], and "assistência" [care] combined with Boolean operator "AND".

The inclusion criteria were: fully available publications from 2001 to 2015 that addressed the guiding question of this study. We excluded the publications that were prior to 2001, not fully available, repeated in different databases, and that did not meet the guiding question of this study. Data crossreferencing were carried out with descriptors such as "HIV", "idoso" [aged people] and "assistência" [care].

The results were interpreted from the variables: methodology, investigated subject, research scenario, descriptors, and theme. Followed by the interpretation and comparison of productions and the elements that comprised each one of them, finding information and relevant evidence on how literature has referred to nursing care of aged people contaminated by the human immunodeficiency virus. 


\section{RESULTS}

Database research resulted in 717 articles in SciELO database, 89 in LILACS, 91 in BDENF, and 58 in Cochrane. After reading the abstracts, we selected 339 studies in SciELO, 60 LILACS, 69 in 60 BDENF and 54 in Cochrane databases. However, among these articles, only a few answered to the guiding question, 5 of them being in SciELO, 02 in LILACS, 04 in BDENF, and 02 in Cochrane. This way, according to the exclusion criteria, we only 13 articles remained in the study sample (Figure 1). We analyzed the variables: order, title, author, journal and objectives (s). As presented and described in Table 1. To do so, we used a data collection instrument, commonly used in integrative literature reviews and adapted from the review model ${ }^{(9)}$.

Among the 13 found articles, three $(23.1 \%)$ were from 2010 $\left(\mathrm{A} 2^{(7)}, \mathrm{A} 3^{(10)}\right.$ and $\left.\mathrm{A} 9^{(16)}\right)$, and two (15.4\%) from $2009\left(\mathrm{~A} 1^{(9)}\right.$ and $\left.A 11^{(17)}\right)$, having one $(7.7 \%)$ publication/year in 2004, 2007, 2008, and from 2011 to 2015. It becomes clear that only two studies were from the last five years (considering the ones until 2015).

We identified that the Brazilian Journal of Sexually Transmitted Diseases published three articles (23.1\%) and Acta Paulista Journal published two (15.4\%). The other publications were in journals such as: Anna Nery School, Saúde em Debate [Health in Debate], Revista de Enfermagem do Centro O Mineiro [O Mineiro Center Nursing Journal], Revista Eletrônica de Enfermagem [Nursing Electronic Journal], Research Journal: Fundamental Care Online, Brazilian Journal of Epidemiology, Interamerican Journal of Psychology, Epidemiology and Health Services; each one of these with a publication $(7.7 \%)$ addressing the theme under study.

Regarding the used methodology, ten publications (76.92\%) used qualitative descriptive methods, usually based on speech or content analysis or documentary research; while three $(23.1 \%)$ performed statistical analysis of epidemiological nature.

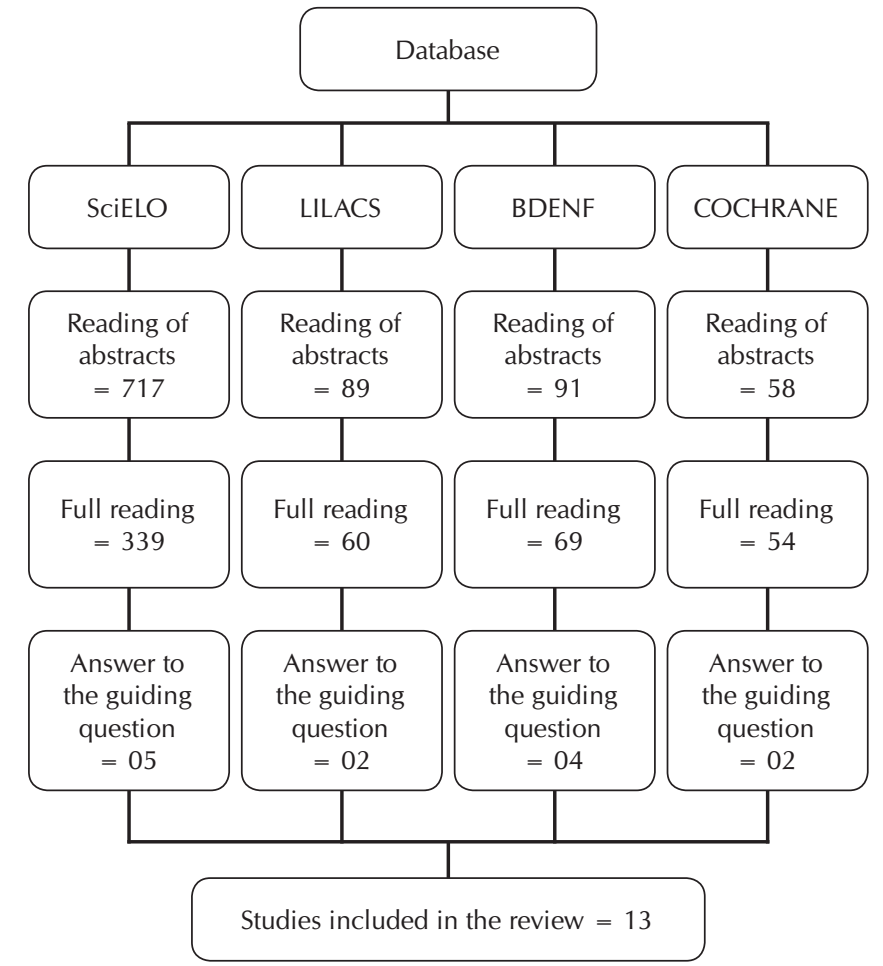

Figure 1 - Flow chart in the search for articles in databases, 2015

Concerning the investigated subjects, 11 publications $(84.62 \%)$ used the aged to approach the topic under study, while two articles (15.38\%) have done so by using nurses as research subjects. When it comes to the research context, most researchers held their studies in outpatient clinics or HIV/Aids specialized centers $(38.46 \%)$, while four of them have held it in hospital units $(30.77 \%)$.

Chart 1 - Characterization of selected articles to analysis, according to order, title, author, journal and objective, Brazil, 2001-2015

\begin{tabular}{|c|c|c|c|c|}
\hline Order & $\frac{\text { Title }}{\text { Author }}$ & Year & Journal & Objective (s) \\
\hline $\mathrm{A} 1$ & $\begin{array}{l}\text { Clinical-epidemiological profile of aged } \\
\text { people with Aids } \\
\text { Souza ACA, Suassuna DSB, Costa SML }{ }^{(9)}\end{array}$ & 2009 & $\begin{array}{l}\text { Brazilian Journal of } \\
\text { Sexually Transmitted } \\
\text { Diseases }\end{array}$ & $\begin{array}{l}\text { To analyze the epidemiological profile of aged } \\
\text { people with Aids in João Pessoa, Paraíba. }\end{array}$ \\
\hline A2 & $\begin{array}{l}\text { Aids in aged people: Experience of patients } \\
\text { AndradeHAS, Silva SK, Santos } M^{(7)}\end{array}$ & 2010 & $\begin{array}{l}\text { Anna Nery School } \\
\text { (printed) }\end{array}$ & $\begin{array}{l}\text { Understand the experience of aged people with human } \\
\text { immunodeficiency syndrome by analyzing participants } \\
\text { from a reference unit of the Unified Health System in } \\
\text { the metropolitan region of Belém, PA. }\end{array}$ \\
\hline A3 & $\begin{array}{l}\text { Nursing diagnoses in patients with Human } \\
\text { Immunodeficiency Virus/lmmunodeficiency } \\
\text { Syndrome Acquired in ambulatory care } \\
\text { Cunha GH, Galvão MTG }{ }^{(10)}\end{array}$ & 2010 & $\begin{array}{l}\text { Acta Paulista de } \\
\text { Enfermagem }\end{array}$ & $\begin{array}{l}\text { To identify nursing diagnoses in patients with } \\
\text { human immunodeficiency virus/immunodeficiency } \\
\text { syndrome (HIV/Aids) acquired in outpatient care. }\end{array}$ \\
\hline A4 & $\begin{array}{c}\text { Knowledge and actions on sexuality in aged } \\
\text { people with HIV/Aids } \\
\text { Okuno MFP, et al }{ }^{(11)}\end{array}$ & 2012 & $\begin{array}{l}\text { Acta Paulista de } \\
\text { Enfermagem }\end{array}$ & $\begin{array}{l}\text { To assess the knowledge and actions on sexuality } \\
\text { in aged people with HIV/Aids that attended a } \\
\text { specialized outpatient clinic; and to identify the } \\
\text { epidemiological profile of these patients. }\end{array}$ \\
\hline A5 & $\begin{array}{c}\text { Perception of life of aged people with HIV/AIDS } \\
\text { that attended a State reference health center } \\
\text { Serra A, et al }{ }^{(12)}\end{array}$ & 2013 & Saúde em Debate & $\begin{array}{l}\text { To analyze the perception of older people with } \\
\text { Aids that attended a State reference health center } \\
\text { from Maranhão, Brazil. }\end{array}$ \\
\hline
\end{tabular}


Chart 1 (concluded)

\begin{tabular}{|c|c|c|c|c|}
\hline Order & $\frac{\text { Title }}{\text { Author }}$ & Year & Journal & Objective (s) \\
\hline A6 & $\begin{array}{l}\text { Benefits of group interaction between } \\
\text { people with HIV/Aids } \\
\text { Souza NR, Vietta EP }\end{array}$ & 2004 & $\begin{array}{l}\text { Brazilian Journal of } \\
\text { Sexually Transmitted } \\
\text { Diseases }\end{array}$ & $\begin{array}{l}\text { To investigate the benefits of group interaction } \\
\text { between people with HIV/Aids; to evaluate the group } \\
\text { relationship as an alternative to outpatient treatment } \\
\text { of people with HIV/Aids, analyzing the several stages } \\
\text { of the process of group formation and development; } \\
\text { to identify evidences of users and staff involved in } \\
\text { group activities, its advantages and disadvantages to } \\
\text { the patients' quality of life. }\end{array}$ \\
\hline A7 & $\begin{array}{c}\text { Managing in the older women care } \\
\text { with HIV/Aids in a infecto-contagious } \\
\text { disease service } \\
\text { Oliveira EC, Leite JL, Fuly PS }\end{array}$ & 2015 & $\begin{array}{l}\text { Revista de Enfermagem } \\
\text { do Centro O Mineiro }\end{array}$ & $\begin{array}{l}\text { To identify the implications of office nursing in the } \\
\text { management of older women care with HIV/Aids. }\end{array}$ \\
\hline A8 & $\begin{array}{c}\text { Nursing diagnoses on security and } \\
\text { protection to people with HIV/Aids } \\
\text { Faria, JO, Silva } \mathrm{GA}^{(15)}\end{array}$ & 2014 & $\begin{array}{l}\text { Revista Eletrônica de } \\
\text { Enfermagem (Online) }\end{array}$ & $\begin{array}{l}\text { To identify nursing diagnoses on security and } \\
\text { protection of Taxonomy II of NANDA-I in people } \\
\text { with HIV/Aids in a hospital of Minas Gerais. }\end{array}$ \\
\hline A9 & $\begin{array}{c}\text { The nurse's role to encourage antiretroviral } \\
\text { therapy in HIV-positive patients } \\
\text { Sá TA, Rembold SM }{ }^{(16)}\end{array}$ & 2010 & $\begin{array}{l}\text { Journal of Research } \\
\text { Fundamental Care } \\
\text { Online }\end{array}$ & $\begin{array}{l}\text { It explores the importance of adhering to } \\
\text { antiretroviral therapy for the survival of HIV-positive; } \\
\text { it identifies the difficulties of patients that adhered to } \\
\text { antiretroviral therapy and/or abandoned treatment } \\
\text { when undergoing outpatient treatment for infectious } \\
\text { and parasitic diseases in Antônio Pedro College } \\
\text { Hospital. }\end{array}$ \\
\hline A10 & $\begin{array}{l}\text { Characteristics of Aids in old age } \\
\text { in a reference hospital from the state } \\
\text { of Ceará, Brazil } \\
\text { Araújo VLB,et al }\left.\right|^{(1)}\end{array}$ & 2007 & $\begin{array}{l}\text { Brazilian Journal of } \\
\text { Epidemiology }\end{array}$ & $\begin{array}{c}\text { To describe the characteristics of Aids in people } \\
\text { with } 60 \text { years of age or more that attended a HIV/ } \\
\text { Aids reference hospital in Ceará from } 989 \text { to } \\
2004 \text {. }\end{array}$ \\
\hline A11 & $\begin{array}{l}\text { Aging with Aids: representations, beliefs and } \\
\text { actions of aged people with HIV } \\
\text { Saldanha AAW, Araújo LF, Souza VC }\end{array}$ & 2009 & $\begin{array}{l}\text { Interamerican Journal } \\
\text { of Psychology }\end{array}$ & $\begin{array}{l}\text { To identify emerging representations regarding HIV } \\
\text { infection in aged people, exploring coping and } \\
\text { social support issues. }\end{array}$ \\
\hline A12 & $\begin{array}{c}\text { The epidemiological profile of Aids in } \\
\text { aged people using health information from } \\
\text { Datasus: truths and challenges } \\
\text { GodoyVS, et al }{ }^{(18)}\end{array}$ & 2008 & $\begin{array}{l}\text { Brazilian Journal of } \\
\text { Sexually Transmitted } \\
\text { Diseases }\end{array}$ & $\begin{array}{l}\text { To identify the epidemiology of diagnosed cases } \\
\text { of Aids in Brazil in individuals with } \geq 60 \text { years. }\end{array}$ \\
\hline A13 & $\begin{array}{c}\text { Clinical and epidemiological characteristics of } \\
\text { aged patients with Aids in a reference hospital } \\
\text { from Teresina, Piauí, Brazil, } \\
\text { from } 1996 \text { to } 2009 \\
\text { Silva HR, et al, } 2011^{(19)}\end{array}$ & 2011 & $\begin{array}{l}\text { Epidemiology and } \\
\text { Health Services }\end{array}$ & $\begin{array}{c}\text { To investigate the epidemiological characteristics } \\
\text { of aged people with Aids that attended a reference } \\
\text { hospital of Teresina, state of Piauí, Brazil. }\end{array}$ \\
\hline
\end{tabular}

From the descriptors used in 13 of the studied publications, 14 (28.57\%) comprised HIV/Aids in its description (considering all had it as focus of study), 8 (16.33\%) comprised nursing, and 8 (16.33\%) comprised aged people. Usually when approaching HIV, studies consider the adolescent's context, leading to small amount of productions around HIV in aged people (its prospects and constraints, for example), which was possible to see in $A 8^{(15)}$ and $A 9^{(16)}$.

From the analysis and complexity of scientific articles, two categories of results arouse, leading to a better presentation of scientific evidences on nursing care to aged people with HIV, these being: Epidemiological profile, perceptions and experiences of aged people with HIV and nursing care to aged people with HIV.

Epidemiological profile, perceptions and experiences of aged people with HIV

As for the epidemiological profile of aged people with HIV, articles identified that the amount of men and women with HIV is almost the same, being 11 (55\%) and nine (45\%), respectively. However, in $\mathrm{A} 10^{(1)}$ and $\mathrm{A} 13^{(19)}$, the number of men was higher than that of women. We also identified $A 12^{(18)}$ reported that in 1995, the relation was of three infected men to one infected woman; in 2005, this value changed from 1.5 to 1 , respectively.

When it comes to sexual orientation, $\mathrm{A} 12^{(18)}$ and $\mathrm{A} 13^{(19)}$ observed 51 (73.9\%) heterosexuals with HIV and only five $(7.2 \%)$ homosexuals. When correlating the profile of these aged people, they mentioned other characteristics, such as: a) low education, with expressive numbers, as the ones pointed out by $\mathrm{A} 1^{(9)}, \mathrm{A} 10^{(1)}, \mathrm{A} 12^{(18)}$ and $\mathrm{A} 13^{(19)}$, verifying it in almost $90 \%$ of the analyzed sample; b) transmission by sexual contact, which represented almost the whole sample, only $\mathrm{A} 13^{(19)}$ showed a case of transmission by drugs injection thanks to needle sharing; c) high number of sexual partners without using condom, despite knowing the risks of such a thing, according to $\mathrm{A} 1^{(9)}, \mathrm{A} 10^{(1)}$, and $\mathrm{A} 12^{(18)}$. 
Regarding the perceptions and experiences reported by the aged after the diagnosis of HIV, publications $\mathrm{A} 2^{(7)}, \mathrm{A} 4^{(11)}, \mathrm{A} 5^{(12)}$ and $\mathrm{A} 11^{(17)}$ pointed out it affected the relationship that they had with their family and friends, which made them feel mad and awkward about $\mathrm{it}^{(7)}$. Some studies highlight social isolation of aged people from family and friends and there are some reports on health professionals that did not identify their signs of depression.

\section{Nursing care to aged people with HIV}

The articles we mention here present nursing care as an unique measure to the care of aged people with HIV, considering it covers issues regarding health education (guidance and clarification), in addition to treatments applied in different perspectives, both in hospitals, in primary health care, in schools or business environments.

In this perspective, studies $\mathrm{A} 3^{(10)}$ and $\mathrm{A} 8^{(15)}$ described that aged people who attended a infectious disease outpatient clinic underwent nursing diagnoses of risks of infection, sexual dysfunction, unhealthy eating, inefficient control of treatment, insomnia, risk of unbalanced nutrition, lack of knowledge, low self-esteem caused by the diagnosis, fear and others. Regarding aged people with HIV, nursing diagnosis is the first step in nursing care.

A3 ${ }^{(10)}$ pointed out "unbalanced nutrition: lower than body requirements" as one of the experienced conditions to aged people with HIV. Other diagnoses mentioned by $A 3^{(10)}$ include factors associated with quality of life, such as the decrease in physical activities (which influences fatigue and weakness), insomnia and sexual dysfunction, in addition to elements involving psychical and social matters.

As for the development of host groups by the nurse, it seems like a reasonable measure in the care of aged people with HIV from the diagnosis to the terminal phase. Care offered under collective perspective of care improves the reception of aged people in a space of mutual identification and exchange of experiences, contributing to a more healthy conception on what it means to have HIV in advanced ages ${ }^{(13)}$.

Articles $\mathrm{A} 6^{(13)}, \mathrm{A} 9^{(16)}, \mathrm{A} 12^{(18)}$ and $\mathrm{A} 13^{(19)}$ considered it was important for nurses to know how to use group activities wisely to avoid patients to see it as something threatening that implies overexposure, which would lead to evasion. But that encourages the performance of daily activities, in addition to the promotion of quality of life.

\section{DISCUSSION}

Despite the small amount of Brazilian published articles on the matter, it was possible to observe important points with the development of this study, such as the way society understands the aged people's sexuality, which might be due to the fact that sex has been seen as a taboo by family and partners for many years. This way, authors ${ }^{(20)}$ reported that it is necessary to plan health actions regarding aged people's sexual demands, because they are associated with the subject's well-being and quality of life. Thus, there is need to evaluate the knowledge of aged people on HIV transmission and prevention, providing them an educational and preventive actions plan.

Studies show that this context is also common in countries of Latin America, as a study carried out in $\mathrm{Cuba}^{(21)}$ to identify the perception of older people regarding the risk of HIV infection; it concluded that the aged had knowledge on the disease but they had no self-perception about the risks of getting virus, showing high risk behaviors. A Columbian researcher ${ }^{(22)}$ points out that the clinical process of the disease in aged people is similar to the one that occurs for younger patients; however, after 65 years, it is possible to see that aged patients show higher risks of opportunistic infections because of the characteristics of aging.

Regarding the patient's sex, we observed contradictory opinions. Some of the analyzed authors report there is an expressive number of infected men when compared to women; however, other researchers report that it is important to highlight that the difference in the ratio men/women has been decreasing. A retrospective and descriptive research carried out in Montevideo, Uruguai ${ }^{(23)}$ also noted these data, identifying the total of admitted and hospitalized with an average age of 63 years and a similar percentage for both sexes $(53 \%$ men and $47 \%$ women). Other studies pointed out similar data ${ }^{(2425)}$.

In Brazil, according to Boletim Epidemiológico [Epidemiological Bulletin] of 2015 "among men, it is possible to observe an increase in the detection rate, mainly among those with [...] 60 years or more in the last 10 years ${ }^{\prime \prime(26)}$. On the other hand, when it comes to mortality, Epidemiological Bulletins from 2013 and 2015 prepared by the Brazilian Ministry of Health reported that, in all age groups, the mortality rate was higher among men compared to women. Among the ones with more than 60 years, we observed an increase of $33.3 \%$ in deaths. Among aged women, with 60 years or more, we observed an increase of $81.3 \%{ }^{(26-27)}$ from 2003 to 2012.

Another mentioned issue was sexual orientation, which has been associated with the risk group in the last decades. We observed that all studies found that most people with HIV are heterosexuals, considering the number of aged heterosexuals is higher than the one for homosexuals. In addition, we noted that aged people still believe in the idea of risk groups such as: homosexuals, prostitutes and young people. This way, the disease becomes common and there is no concerns on the use of condoms ${ }^{(20)}$. The assessed studies clarify that there is no groups of risk, only behaviors of risk ${ }^{(25,28)}$.

The analysis of the results allowed us to identify that when older people attend a health service, it takes days or even a whole year for them to be diagnosed with HIV. Many cases are limited to the secondary or tertiary network, when seen as opportunistic infections, having late diagnosis. Authors state that this situation might be associated with the socioeconomic level and low education, which would justify why some patients took so long to attend a health service ${ }^{(25)}$.

The Brazilian Ministry of Health reports that the aged population is the most affected by lack of early diagnosis.

We observed the highest proportions of late diagnosis in the aged population of 60 years and more, except in 2011. This ratio between aged people is three times higher than that observed among young people from 18 to 24 years old in October $2015\left(11.9 \%\right.$ and $38.1 \%$, respectively) ${ }^{(27)}$.

We recognize the importance of nursing care to aged people with HIV regarding educational/preventive actions and suspicions concerning the disease. Considering the nurse is the professional who is mostly in contact with the patient contributes to the inclusion and use of the Nursing Care System (NCS), which considers consults, diagnoses, planning, execution and 
evaluation as essentials; to do so, the COFEN resolution no. $358 / 2009$ support the nurses, being a basis for the choice and determination of actions or interventions to promote a certain result, such as the promotion a quality of life ${ }^{(29)}$.

However, even when the nurse is in direct contact with the patient, these professionals still need to integrate actions associated with sexuality to help patients to overcome the disease. Studies on aged people's sexuality and nursing care integration are still scarce ${ }^{(30)}$.

In this perspective, other studies suggest that the promotion of oral hygiene is also an assignment for nurses. These authors approach oral hygiene measures for patients with candidiasis, or that might develop it, as essential in a holistic from perspective that needs to focus on the customer ${ }^{(24)}$. Which makes it necessary for the nurse to not only follow drug therapy, but an approach characterized by adequate and salutary guidance ${ }^{(25,28,30)}$.

When thinking about the nutrition and the quality of life of these aged people, we face issues associated with food guidance, sexual orientation, use of drugs (antiretroviral drugs) and emotional diseases, especially when part of the patient's family and friends discriminate them, which leads to their social isolation and the possibility of developing depression and suicide ${ }^{(32)}$.

This fact leads to nurse's responsibility on the development of care aimed at implementing guidelines that allow the aged to have quality of life, despite the difficulties of HIV and the ones enhanced by the HIV diagnosis, according to NANDA (North American Nursing Diagnosis Association): hopelessness, changes in urinary behavior, need for resolution strategies for family stress, fatigue, ineffective management of treatments, changes in oral mucosa, changes in nutrition and risks of infection ${ }^{(32)}$. From a nutritional perspective, a study carried out in Spain ${ }^{(33)}$ with hospitalized aged people with immunologic deficiency, such as HIV, identified that malnutrition is associated with sensory and oral cavity disorders, dysphagia, anorexia, cognitive deficit and food addiction.

It is important to highlight that the aged people with HIV approached by research are from low socioeconomic levels and have low education. In a study conducted in a Polyclinic Institute in Santiago, Cuba ${ }^{(21)}$, also showed these results regarding education; women had primary level of education while males had the secondary level, considering that nobody reported having higher education.

Another note approaches the need to question the scope of diagnoses and nursing actions, that are usually mostly focused on individuals, as they were the only ones responsible for their health, not suggesting enough action and measures that can actually improve social inequality and the understanding of the population on the disease ${ }^{(34)}$.

Regarding these data, a study conducted in Fortaleza describes relevantly the hard work of nursing in Specialized Outpatient Services for people with HIV/Aids, considering the users' low education and the predominance of the biomedical model. Nurse reports show that they have difficulties in continuing nursing consults because some of their patients do not come back for it, being only interesting in attending medical consults to receive antiretroviral drugs ${ }^{(35)}$.

As for the participation of aged people in educational activities, we noted that the nurse needs to have a more active posture, conducing playful exercises and seeing the participant's knowledge as a way of calling their attention to the problem and establishing a more close relationship that can develop even more with confidence ${ }^{(13)}$, as many of them can see group activities as unique opportunities of expressing their fears. Such measure shows to be really useful for aged people with HIV, considering that in group exercises, they are encouraged to reflect on the meaning of the worsening of the disease, and to improve its knowledge and interrelation with the other participants. The nurse needs to use strategies that might contribute significantly with the aged people's health, understanding that the required approach does not need to be at individual level ${ }^{(13,26)}$.

In addition to the group approach, care at individual level, when well administered, contributes significantly to the wellbeing of aged people with HIV; thanks to this approach, the nurse considers the characteristics of each subject when clarifying some basic aspects that define HIV infection, especially when it comes to the aging process ${ }^{(14)}$.

It becomes essential that the nurse's role be performed according to a multidisciplinary and interdisciplinary basis to provide a balanced and holistic care to older people with HIV, allowing a adequate response to the real needs of each patient to ensure their quality of life.

\section{Limitations of the study}

From the articles found in literature, we could observe a low number of updated articles that answered to the guiding question of this study. We noted that there is a concern on the scientific field regarding the aged people sex life. However, qualitative studies do not approach "humanized listening" and the effective participation of the nurse as a educator. We believe that trough further studies in primary health care it would be possible to understand issues on the sexuality of aged people and the difficulties of including educational actions for this group. It is worth mentioning that after the development and conclusion of the study, we analyzed the methodology and the level of evidence of the found research.

\section{Contributions to the area of nursing, and public health}

This research points out that there are many aged people infected with HIV who have multiple partners and are not using condoms. Considering the severity of the disease and its quick dissemination due to the increase in the number of infected aged people, we think there is need to develop public policies on this matter. When analyzing the Aged People Statute and the National Health Policy for Aged People, we observed that it does not approach sexuality in a significant way, maybe for both being obsolete. We also identified the lack of preparation of health professionals, including nurses, to deal with this group, which shows resistance towards the treatment and acceptance.

\section{FINAL CONSIDERATIONS}

The literature approaches nursing care by associating it with epidemiological aspects. It shows elements that maximize the dissemination of aggravations, such as low education/instruction, or the resistance regarding the made recommendations, or within individual and collective environment. This way, texts say that the nurse can contribute more to the care of aged people by employing interventions both in group and individual level from the identification of problems associated with the 
diagnose of HIV that should receive more attention during the diagnose to better define the actions to be provided to patients.

However, we consider that studies see nursing care from a perspective based on NANDA's diagnoses, from a strong and individualizing approach, almost ignoring the socials aspects associated to it. Group and educational interventions seem to still be predominantly based on traditional practices, and/or techniques that do not question the context of life, the values, the culture, and the access to social policies concerning HIV infection and the ways to deal with it.

\section{ERRATUM}

Article "Integrative review of literature: nursing care to aged people with HIV", with number of DOI: http://dx.doi. org/10.1590/0034-7167-2017-0264, published in the journal Revista Brasileira de Enfermagem, v71(suppl 2):884-92:

References 28 and 30 should be deleted.

On page 888,

Where it read:

"In Brazil, according to Boletim Epidemiológico [Epidemiological Bulletin] of 2015 "among men, it is possible to observe an increase in the detection rate, mainly among those with [...] 60 years or more in the last 10 years"(26)."

Read:

"In Brazil, according to Boletim Epidemiológico [Epidemiological Bulletin] of 2015 "among men, it is possible to observe an increase in the detection rate, mainly among those with [...] 60 years or more in the last 10 years"(27)."

Where it read:

"The assessed studies clarify that there is no groups of risk, only behaviors of risk ${ }^{(28)}$."

Read:

"It is considered that there are no groups at risk but rather behaviors and vulnerabilities ${ }^{(29)}$."

On page 888 and 889 ,

Where it read:

"The analysis of the results allowed us to identify that when older people attend a health service, it takes days or even a whole year for them to be diagnosed with HIV. Many cases are limited to the secondary or tertiary network, when seen as opportunistic infections, having late diagnosis. Authors state that this situation might be associated with the socioeconomic level and low education, which would justify why some patients took so long to attend a health service ${ }^{(25)}$."

\section{Read:}

"The analysis of the results allowed us to identify that when older people attend a health service, it takes days or even a whole year for them to be diagnosed with HIV. Many cases are limited to the secondary or tertiary network, when seen as opportunistic infections, having late diagnosis. Authors state that this situation might be associated with the socioeconomic level and low education ${ }^{(25)}$, which would justify why some patients took so long to attend a health service."

On page 889,

Where it read:

"However, even when the nurse is in direct contact with the patient, these professionals still need to integrate actions associated with sexuality to help patients to overcome the disease. Studies on aged people's sexuality and nursing care integration are still scarce ${ }^{(32) \prime \prime}$.

Read:

"However, even when the nurse is in direct contact with the patient, these professionals still need to integrate actions associated with sexuality to help patients to overcome the disease $\mathrm{e}^{(35)}$. Studies on aged people's sexuality and nursing care integration are still scarce".

Where it read:

"When thinking about the nutrition and the quality of life of these aged people, we face issues associated with food guidance, sexual orientation, use of drugs (antiretroviral drugs) and emotional diseases, especially when part of the patient's family and friends discriminate them, which leads to their social isolation and the possibility of developing depression and suicide ${ }^{(34)}$."

Read:

"When thinking about the nutrition and the quality of life of these aged people, we face issues associated with food guidance, sexual orientation, use of drugs (antiretroviral drugs) and emotional diseases, especially when part of the patient's family and friends discriminate them, which leads to their social isolation and the possibility of developing depression and suicide ${ }^{(31)}$."

On page 889, where it read:

"The nurse needs to use strategies that might contribute significantly with the aged people's health, understanding that the required approach does not need to be at individual level ${ }^{(13,26)}$." $^{\prime \prime}$

Read:

"The nurse needs to use strategies that might contribute significantly with the aged people's health, understanding that the required approach does not need to be at individual level ${ }^{(13)}$." 


\section{REFERENCES}

1. Araújo VLB, Brito DMS, Gimeniz MT, Queiroz TA, Tavares CM. Características da Aids na terceira idade em um hospital de referência do Estado do Ceará, Brasil. Rev Bras Epidemiol [Internet]. 2007[cited 2016 Jun 02];10(40):544-54. Available from: http://www.scielo.br/pdf/rbepid/v10n4/12.pdf

2. Souza M, Marcon SS, Bueno SMV, Carreira L, Baldissera VDA. A vivência da sexualidade por idosas viúvas e suas percepções quanto à opinião dos familiares a respeito. Rev Saúde Soc[Internet]. 2015[cited 2017 Apr 21];24(3):936-44. Available from: http:// www.scielo.br/pdf/sausoc/v24n3/0104-1290-sausoc-24-03-00936.pdf

3. Closs VE, Schwanke CHA. A evolução do índice de envelhecimento no Brasil, nas suas regiões e unidades federativas no período de 1970 a 2010. Rev Bras Geriatr Gerontol [Internet]. 2012 [cited 2017 Apr 21];15(3):443-58. Available from: http://www.scielo. br/pdf/rbgg/v15n3/v15n3a06.pdf

4. Teva I, Bermúdez, MP, Ramiro MT, Buela-Casal G. Situación epidemiológica actual del VIH/SIDA en Latinoamérica. Rev Med Chile [Internet]. 2012 [cited 2017 May 29];140:50-8. Available from: http://www.scielo.cl/pdf/rmc/v140n1/art07.pdf

5. Brasil. Ministério da Saúde. Secretaria de Vigilância em Saúde. Departamento de DST, Aids e Hepatites Virais. Boletim Epidemiológico - Aids e DST. Ano IV - nº 1 - até semana epidemiológica 26a - dezembro de 2013. Brasília, DF; [Internet]. 2015[cited 2017 Apr 21]. Available from: http://www.aids.gov.br/publicacao/2015/boletim-epidemiologico-aids-e-dst-2015

6. Borges GM, Ervatt LR, Jardim AP. Mudança demográfica no Brasil no início do século XXI: subsídios para as projeções da população [Internet]. Rio de Janeiro: IBGE; 2015[cited 2017 Apr 21]. Available from: https://biblioteca.ibge.gov.br/visualizacao/ livros/liv93322.pdf 2015

7. Uchôa YS, Costa DCA, Silva Jr IAP, Silva STSE, Freitas WMTM, Soares SCS. A sexualidade sob o olhar da pessoa idosa. Rev Bras Geriatr Gerontol[Internet]. 2016 [cited 2017 Apr 21];19(6):939-49. Available from: http://www.scielo.br/pdf/rbgg/v19n6/pt_18099823-rbgg-19-06-00939.pdf

8. Crossetti MGO. Revisão integrativa de pesquisa na enfermagem o rigor científico que Ihe é exigido [editorial]. Rev Gaúcha Enferm[Internet]. 2012 [cited 2017 Apr 21];(2):8-9. Available from: http://www.scielo.br/pdf/rgenf/v33n2/01.pdf

9. Sousa ACA, Suassuna DSB, Costa SML. Perfil clínico-epidemiológico de idosos com Aids. DST J bras Doenças Sex Transm[Internet]. 2009 [cited 2016 Jun 02];21(1):22-6. Available from:http://www.dst.uff.br/revista21-1-2009/5-Perfil\%20ClinicoEpidemiologico\%20JBDST\%2021(1)\%202009.pdf

10. Cunha GH, Galvão MTG. Nursing diagnoses in patients with Human Immunodeficiency Virus/Acquired Immunodeficiency Syndrome in outpatient care. Acta Paul Enferm[Internet]. 2010 [cited 2016 Jun 02];23(4):526-32. Available from: http://www. scielo.br/pdf/ape/v27n1/pt_0103-2100-ape-27-01-00040.pdf

11. Okuno MFP, Fram DS, Batista REA, Barbosa DA, Belasco AGS. Knowledge and attitudes about sexuality in the elderly with HIV/ AIDS. Acta Paul Enferm[Internet]. 2012 [cited 2016 Jun 02];25(1):115-21. Available from: http://www.scielo.br/pdf/ape/v25nspe1/ pt_18.pdf

12. Serra A, Sardinha AHL, Pereira ANS, LIMA SCVS. Percepção de vida dos idosos portadores do HIV/AIDS atendidos em centro de referência estadual. Saúde Debate[Internet]. 2013[cited 2016 Jun 02];37(97):294-304. Available from: http://www.scielo.br/pdf/ sdeb/v37n97/v37n97a11.pdf

13. Souza NR, Vietta EP. Benefícios da interação grupal entre portadores do HIV/Aids. DST J Bras Doenças Sex Transm[Internet]. 2004 [cited 2016 Jun 02];16(2):10-17. Available from: http://www.dst.uff.br/revista16-2-2004/2.pdf

14. Oliveira EC, Leite JL, Claro FPS. A gerência do cuidado à mulher idosa com HIV/AIDS em um serviço de doenças infectoparasitárias. Rev Enf Cent O Min[Internet]. 2015 [cited 2016 Jun 02]. Available from: http://www.seer.ufsj.edu.br/index.php/ recom/article/view/634

15. Faria JO, Silva GA. Diagnósticos de enfermagem do domínio segurança e proteção em pessoas com HIV/Aids. Rev Eletron Enferm[Internet]. 2014[cited 2016 Jun 02];16(1):93-9. Available from: https://www.fen.ufg.br/fen_revista/v16/n1/pdf/v16n1a11.pdf

16. Sá TA, Rembold SM. O papel do enfermeiro (a) no incentivo à adesão à terapia antirretroviral em pacientes soropositivos. Rev Pesq: Cuid Fund [Internet]. 2010 [cited 2016 Jun 02];33:15-21. Available from: http://www.seer.unirio.br/index.php/ cuidadofundamental/article/view/1128

17. Saldanha AA, Araújo LF, Sousa VC. Envelhecer com Aids: representações, crenças e atitudes de idosos soropositivos para o HIV. Interam J Psychol[Internet]. 2009 [cited 2016 Jun 02];43(2):323-32. Available from: http://pepsic.bvsalud.org/pdf/rip/v43n2/ v43n2a13.pdf

18. Godoy VS, Canini SRMS, Gir E, Silva EC, Ferreira MiD. O perfil epidemiológico da AIDS em idosos utilizando sistemas de informações em saúde do DATASUS: realidades e desafios. DST J Bras Doenças Sex Transm[Internet]. 2008 [cited 2016 Jun 02];20(1):7-11. Available from: http://www.dst.uff.br/revista20-1-2008/1.pdf

19. Silva HR, Marreiros MDOC, Figueiredo TS, Figueiredo MLF. Características clínico-epidemiológicas de pacientes idosos com Aids em hospital de referência, Teresina-PI, 1996 a 2009. Epidemiol Serv Saúde [Internet]. 2011 [cited 2016 Jun 02];20(4):499-507. 
Available from: http://scielo.iec.pa.gov.br/pdf/ess/v20n4/v20n4a09.pdf

20. Bittencourt GKGD, Moreira MASP, Meira LCS, Nóbrega MML, Nogueira JA, Silva AO. Beliefs of older adults about their vulnerability to HIV/Aids, for the construction of nursing diagnoses. Rev Bras Enferm[Internet]. 2015 [cited 2017 May 29];68(4):579-85 Available from: http://www.scielo.br/pdf/reben/v68n4/0034-7167-reben-68-04-0579.pdf

21. Estrada JAF, Hechavarría OB, Fernández MCP, Tabares L, Fong JO. Percepción de riesgo de sida en adultos mayores de un área de salud. MEDISAN [Internet]. 2015 [cited 2017 May 29];19(9):11-7 Available from: http://scielo.sld.cu/pdf/san/v19n9/san07199.pdf

22. Escobar AM, Díaz R, Posada A. Criptococosis diseminada en anciano con VIH. Acta Méd Colomb [Internet]. 2011 [cited 2017 May 29];36(2):85-9. Available from: http://www.scielo.org.co/pdf/amc/v36n2/v36n2a06.pdf

23. Bruno L, Laborde G, Broli F, Pérez G, Dufrechou C.Vih-Sida: complicaciones neurológicas de los pacientes asistidos en un hospital general de adultos. Arch Med Interna [Internet]. 2013 [cited 2017 May 29];35(1). Available from: http://www.scielo.edu. uy/pdf/ami/v35n1/v35n1a03.pdf

24. Bertotti MEZ. Autopercepção da saúde bucal de idosos em interface com doenças crônicas e uso de medicações. Arq Med Hosp Fac Cienc Med[Internet]. 2015[cited 2017 Apr 23];60:54-60. Available from: http://www.fcmscsp.edu.br/images/Arquivos_ medicos/2015/02-AO81.pdf

25. Alencar RA, Ciosak S. Aids em idosos: motivos que levam ao diagnóstico tardio. Rev Bras Enferm [Internet]. 2016 [cited 2017 Apr 23];69(6):1140-46. Available from: http://www.scielo.br/pdf/reben/v69n6/0034-7167-reben-69-06-1140.pdf

26. Brasil. Ministério da Saúde. Secretaria de Vigilância em Saúde. Departamento de DST, Aids e Hepatites Virais. Boletim Epidemiológico - Aids e DST. Ano III - $\mathrm{n}^{\mathrm{o}} 1-27^{\mathrm{a}}$ à $52^{\mathrm{a}}$ semanas epidemiológicas - julho a dezembro de 2013 . Ano III - $\mathrm{n}^{\mathrm{o}} 1-01^{\mathrm{a}}$ à $26^{\mathrm{a}}$ semanas epidemiológicas - janeiro a junho de 2014. Brasília, DF [Internet]. 2014[cited 2016 Jun 02]. Available from: http:// www.aids.gov.br/sites/default/files/anexos/publicacao/2014/56677/boletim_2014_final_pdf_15565.pdf

27. Brasil. Ministério da Saúde. Secretaria de Vigilância em Saúde. Departamento de DST, Aids e Hepatites Virais. Boletim Epidemiológico - Aids e DST. Ano IV - $\mathrm{n}^{\mathrm{o}} 1$ - da $27^{\mathrm{a}}$ à 53a semana epidemiológica - julho a dezembro de 2014 . Ano IV - $\mathrm{n}^{\mathrm{o}} 1$ - da $01^{\mathrm{a}}$ à $26^{\mathrm{a}}$ semana epidemiológica - janeiro a junho de 2015. Brasília, DF [Internet]. 2015 [cited 2016 Jun 02]. Available from: http://www.aids.gov.br/sites/default/files/anexos/publicacao/2015/58534/boletim_aids_11_2015_web_pdf_19105.pdf

28. Brasil. Ministério da Saúde. Secretaria de Vigilância em Saúde. Coordenação-Geral de Desenvolvimento da Epidemiologia em Serviços. Guia de Vigilância em Saúde[Internet]. 2016[cited 2017 Apr 23]. Available from: http://portalarquivos.saude.gov.br/ images/pdf/2016/agosto/25/GVS-online.pdf

29. Conselho Federal de Enfermagem. Resolução COFEN - 358 de 2009. Dispõe sobre a Sistematização da Assistência de Enfermagem e a implementação do Processo de Enfermagem em ambientes, públicos ou privados, em que ocorre o cuidado profissional de Enfermagem, e dá outras providências [Internet]. 2009 [cited 2016 Jun 02]. Available from: https://enfermagem.jatai.ufg.br/ up/194/o/Resolu\%C3\%A7\%C3\%A3o_n\%C2\%BA358-2009.pdf

30. Cruz GE, Ramos LR. Functional limitation and disabilities of older people with acquired immunodeficiency syndrome. Acta Paul Enferm[Internet]. 2015 [cited 2017 Apr 23];28(5):488-93 Available from: http://www.scielo.br/pdf/ape/v28n5/en_1982-0194ape-28-05-0488.pdf

31. Nogueira GS, Seidl EMF. Associação entre percepção de doença e ansiedade, depressão e autoeficácia em pessoas com HIV/ Aids. Temas Psicol[Internet]. 2016 [cited 2017 Apr 23];24(2):595-608. Available from: http://pepsic.bvsalud.org/pdf/tp/v24n2/ v24n2a12.pdf

32. North American Nursing Diagnosis Association. Nanda. International, diagnósticos enfermeros: definiciones y clasificación, 2012-2014. Elsevier. 2013.

33. Artaza Artabe I. Infecciones por Inmunodeficiencias en Anciano Institucionalizados. Rev Esp Geriatr Gerontol [Internet]. 2007[cited 2017 May 29];42(1):68-74. Available from: http://www.elsevier.es/es-revista-revista-espanola-geriatria-gerontologia124-articulo-infecciones-por-inmunodeficiencias-ancianos-institucionalizados-S0211139X07735898

34. Goldenberg P, Marsiglia RMG, Gomes MHA. O Clássico e o Novo: tendências, objetos e abordagens em ciências sociais e saúde [Internet]. Rio de Janeiro: Fiocruz, 2003[cited 2017 Apr 23]. Available from: books.scielo.org/id/d5t55/pdf/ goldenberg-9788575412510.pdf

35. Macêdo SM, Miranda KCL, Silveira LC, Gomes AMT. Nursing care in Specialized HIV/Aids Outpatient Services. Rev Bras Enferm [Internet]. 2016 [cited 2017 May 29];69(3):483-8. Available from: http://www.scielo.br/pdf/reben/v69n3/0034-7167reben-69-03-0515.pdf 